\title{
A STUDY ON THE ATTITUDE OF STUDENTS FROM THE NATIONAL SPORTS ACADEMY TO FOREIGN LANGUAGE ACQUISITION IN CONNECTION WITH THEIR FUTURE PROFESSIONAL REALIZATION
}

\author{
Tatiana Hristakieva ${ }^{1}$
}

\begin{abstract}
The purpose of the research was to study the attitude of students from the National Sports Academy "V. Levski", Sofia, to foreign language learning in connection with their future profession as sport specialists, and their interest in using interactive learning techniques in the foreign language courses of the Academy. An enquiry was conducted at the end of the winter term of 2019-2020 academic year with students in the undergraduate programs of the Faculty of Pedagogy and the Faculty of Sport of the National Sports Academy. A questionnaire was used with 12 questions related to the evaluation of students' foreign language learning needs and the most appropriate sources and strategies for language acquisition. The subjects of the study were 65 students, 44 men and 21 women, at the age of 19-20. The statistical methods used for the research were alternative analysis, variance analysis and Pearson's chi-squared test $\left(\mathrm{x}^{2}\right)$. The results from the study show that students are mostly interested in the practical application of foreign language learning. They need to develop their productive language skills - oral communicative and writing skills, in order to use the language directly. Computer games and activities in the internet can act as a close to natural environment enhancing language acquisition. Another important conclusion from the survey is that students recognize using foreign languages as an important part of their professional qualification with reference to future career development.
\end{abstract}

UDC Classification: 81`33, DOI: https://doi.org/10.12955/pss.v1.52

Keywords: students, attitude, language, learning

\section{Introduction}

The processes of globalization and the development of information technologies in the last thirty years have led to significant changes in the field of education. The huge amount of new information presents the question of constant upgrading personal knowledge, skills and qualification, and learning throughout life. This also refers to sport specialists - coaches and physical education teachers. They have to be familiar with the latest developments and innovations in their field, in order to apply the best training and teaching methods in their work. The Bologna declaration, ratified by 29 countries in 1999, including Bulgaria, has acted as a strong stimulus for European integration in education. A unified system for compatibility and recognition of diplomas and professional qualifications has been created, offering opportunities for the exchange of specialists in the member countries of the European Union. The European Credit Transfer and Accumulation System (ECTS) for comparing academic credits, and the Erasmus exchange programs have allowed for higher education students and lecturers to study or specialize for a period of time in universities of other European countries (Mileva, 2019). Lecturers and students from the National Sports Academy "V. Levski", Sofia have also participated in Erasmus programs. In this respect using foreign languages has become an important requirement for students from the Academy, who would like to participate in the exchange programs with partner universities abroad.

Sport has a special mission in Europe and around the world. It acts as an ambassador for the establishment of friendly relations among nations. It creates job opportunities and influences the economic development of many countries. Sport activities can help people fight stress, isolation and the diseases of sedentary lifestyle. "It generates important values such as team spirit, solidarity, tolerance and fair play, contributing to personal development and fulfilment" (White Paper on Sport, 2007). Sport specialists - coaches, lecturers and physical education teachers have an important task in popularizing sports and organizing sports activities among people in their countries. Using foreign languages for the purposes of international communication and professional development is of great importance for sport specialists. It can help to improve their qualification and lead to better social recognition and satisfaction with their work (Ivanova and Mileva, 2019).

The dynamic developments in contemporary education have led to the introduction of dialogic pedagogy, aiming at active participation of teachers and students in the learning process, expressing opinions and solving problems together (Mileva, 2012). Interactive learning methods are closely related to dialogic pedagogy. They are based on active communication between the group members, exchanging

\footnotetext{
${ }^{1}$ National Sports Academy “V. Levski”, Sofia, Bulgaria, hristakieva@yahoo.com
} 
ideas, playing games, working on projects. In interactive learning the roles of students and teachers are changed. Students are the active participants in the process of learning, while the teacher/lecturer acts as an assistant and consultant in the course of study (Krasteva, 2003; Ivanov, 2004; Gjurova, 2007).

Interactive learning methods are also applied in foreign language learning methodology. Social interactions for the achievement of specific goals provide suitable conditions for foreign language acquisition. Interaction is at the heart of communication, according to H. Brown (1994). The exchange of information and ideas between participants sustain the interest in communication. Foreign language learning uses many different interactive techniques in order to enhance the process of language acquisition, such as role play, discussions, problem-solving tasks, etc. Interactive language learning with its close to natural way of exchanging information could be very suitable in the specialized foreign language learning courses for sport students.

\section{Methodology}

The purpose of the research was to study the attitude of students from the National Sports Academy "V. Levski", Sofia, to foreign language learning in connection with their future profession as specialists in the field of physical education and sport, and their interest in using interactive learning techniques in the specialized language courses of the Academy. A questionnaire was prepared with 12 questions related to the evaluation of students' foreign language learning needs and the most appropriate sources and strategies for language acquisition. Most of the questions were multiple choice, two of them had options for open answers. The enquiry was conducted at the end of the winter term of 2019-2020 academic year with students in the undergraduate programs of the Faculty of Pedagogy and the Faculty of Sport of the National Sports Academy. The subjects of our study were 65 students, 44 men and 21 women, at the age of 19-20. The statistical methods used for the research were alternative analysis, variance analysis and Pearson's chi-squared test $\left(\mathrm{x}^{2}\right)$.

\section{Results and Discussion}

The analysis of the results from the enquiry shows that to the question of how often they used English for the purposes of their education and sport practice, according to a five level scale (very often; often; rarely; almost never; never), $20.0 \%$ of the respondents answered that they used English very often, 44.8 $\%$ replied that they used it often, and $30.8 \%$ answered that they used it rarely. From these results we can presume that the majority of the persons in the enquiry (64.8\%) often need to use English in their education and sports practice. Maybe this is a logical consequence of students' easy access to numerous internet sites in English.

The next question required from students to evaluate their own basic English language skills - listening, oral communication, reading and writing, using a four level scale (not good; good; very good; excellent). The results show that nearly half of the students evaluated their basic language skills as good: listening $-43.1 \%$ of the respondent; oral communication $-46.2 \%$ of the respondent; reading $-47.7 \%$; writing $47.7 \%$. This fact maybe signifies students' impartial judgement of their language skills and their awareness of the need for improvement.

Another question referred to the sources of their present English language knowledge and skills: their secondary school education; additional language courses; participating in games and activities on internet; watching films; or other sources, which they were supposed to specify. Most of the respondents pointed more than one of the five options presented. However, the most popular sources were - school education pointed by $49.2 \%$ of the respondents, internet games and activities - by $47.7 \%$ of the respondents and watching films - by $40.0 \%$. Watching films has long been recognized as a useful activity for language learning, but from the acquired results we could make the conclusion that, apart from learning at school, modern technologies are another useful means of foreign language acquisition. A possible explanation might be that online games and activities provide a "close to natural" environment for students to learn the language, provoking their curiosity and focusing their attention not on language learning, but on the tasks (explained in English), in order to solve the problems of the game or activity and to achieve its goals.

In the following question respondents had to specify which of the skills - listening, oral communication, reading and writing they needed to improve (Figure 1). Oral communication and writing skills were the ones specified as most needed by students in the enquiry $-52.3 \%$ of them answered they needed to improve their oral communication and $46.2 \%$ - their writing skills. In other words, most of the 
respondents needed to improve their productive language skills. It is well known that language production is the more difficult part of language learning. It requires a suitable environment - other persons and means of exchanging oral or written information. In this respect interactive language learning, working on tasks, exchanging information and solving problems in pairs and small groups can be very useful (Brown, 1994; Prabhu, 1987; Willis,1996).

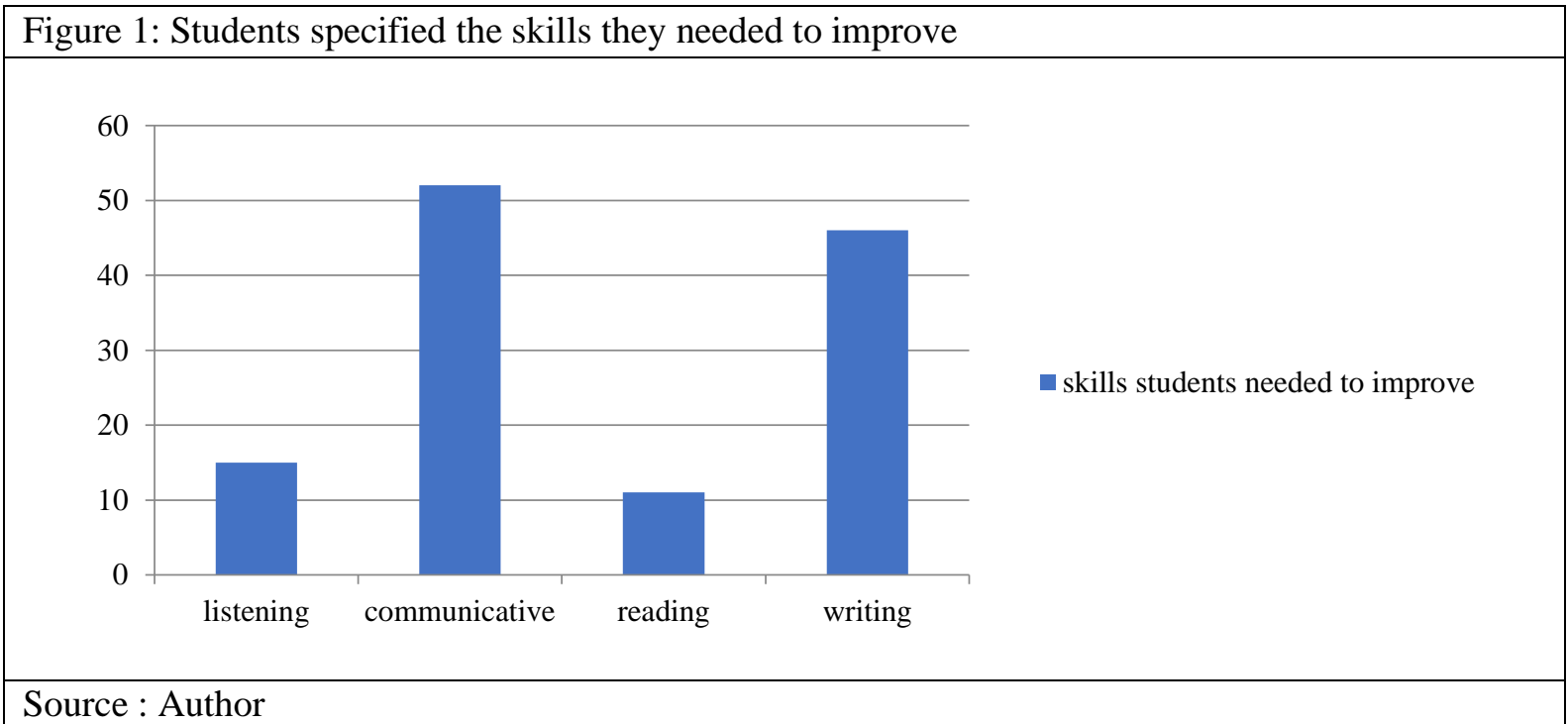

On the question regarding the sources of sport information in English the students use most often, the acquired results are quite significant. $81.5 \%$ of the respondents specify the internet as the most often used source of sport information, $18.5 \%$ point towards television and radio programs, $9.2 \%$ refer to specialized books about sports, and 3.1\% read sports articles in newspapers and magazines. Obviously contemporary generations prefer using modern technologies for information and learning. In fact, most of the specialized sport literature, press news and articles can be easily accessed online.

In the following question the participants in the survey had to specify which of the activities they found most useful for language learning - reading specialized sport texts, discussions on a sport topic, grammar exercises, writing tasks on a sport topic, listening tasks on a sport topic. $49.2 \%$ of the respondents specified "discussions on a sport topic" as the most useful activity for language learning, followed by "listening tasks on a sport topic" $-33.8 \%$ of respondents, and "reading specialized sport texts" $-29.2 \%$ of respondents. The other two activities "writing tasks on a sport topic" (24.6\%) and "grammar exercises" (23.1\%) were recognized as useful by a smaller percent of respondents. Again it is visible from these results that the ability to communicate with people from other countries - to be able to understand them and get understood is most important for the subjects of the research. The knowledge of grammar and writing skills are a bit disregarded, because they also require the conscious effort to practise and learn language forms and spelling rules. Athletes are generally active types of persons and sitting at the writing table for a long time is not a typical activity for them.

The next two questions were quite essential for the research. In the first question the respondents were asked to evaluate the importance of using a foreign language for their professional development as physical education and sport specialists, according to a four level scale (very important; important; not very important; irrelevant). The results were notable $-70.8 \%$ replied that it was "very important" for them (Figure 2). In the following question the respondents had to express their opinion whether using a foreign language could be considered as part of the professional competences and qualification of physical education and sport specialists. $66.2 \%$ of the respondents were "definitely positive" and $23.1 \%$ - "quite positive" that speaking a foreign language should be considered as part of the professional qualification of sport specialists. Obviously, students appreciate the practical need of using a foreign language, in order to have direct access to specialized literature, to be able to follow sport related TV programs, documentaries and online sources. These results represent students' willingness to communicate with colleagues from other countries, to gain new information, to exchange ideas and experience in the field of physical education and sport training. 


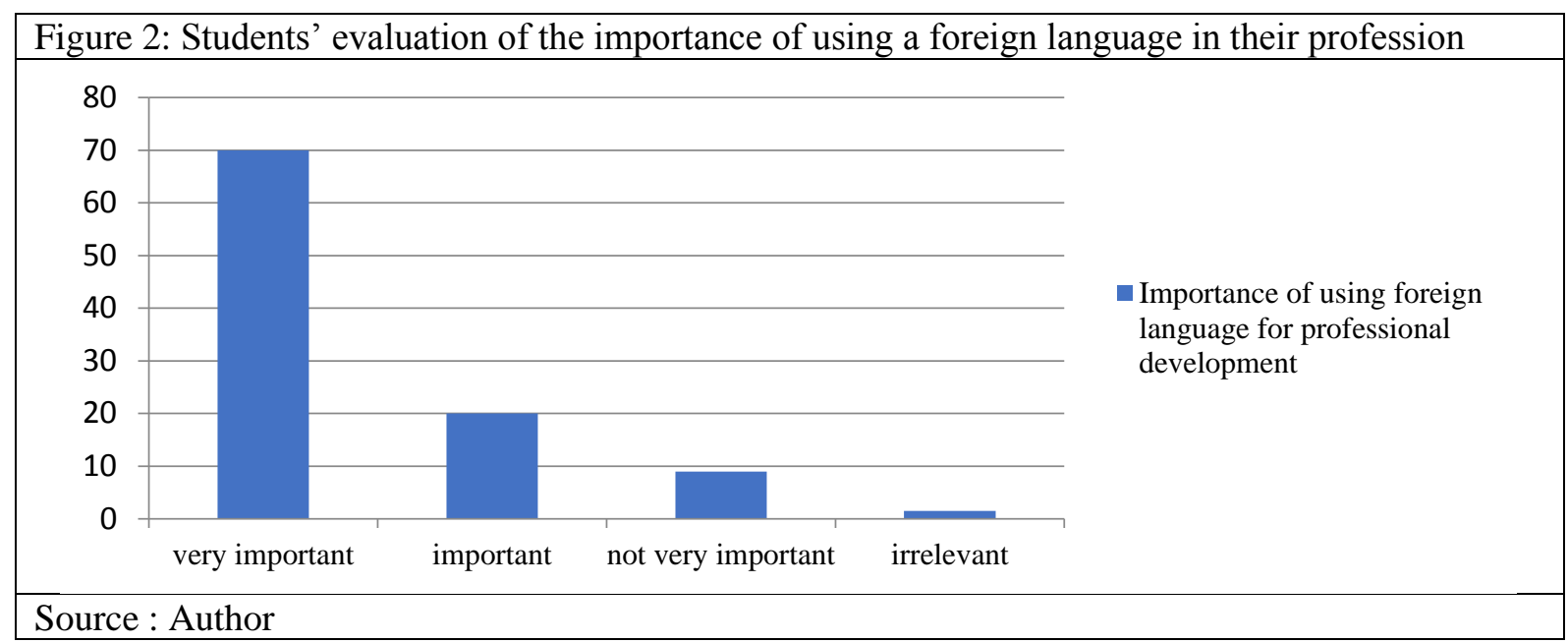

The last four questions referred to students' interest in including interactive techniques in the specialized foreign language courses at the National Sports Academy. 58.5\% of the respondents stated that they were familiar with interactive learning, however only $12.3 \%$ noted that they had participated in that kind of activities before. $53.8 \%$ of the subjects of the research are first year and $30.8 \%$ are second year students at the Academy. Half of the respondents completed their secondary education at specialized sport schools (24.6\%) or foreign language schools (29.2\%.), and the other half (40.0\%) graduated from specialized technical schools. The presented results suggest that they did not have much interactivity in their secondary school education. The greater part of the respondents (69.2\%) expressed a positive attitude to taking part in presentations, games and other interactive forms of learning in the language courses. $63.1 \%$ expressed their positive attitude to working in groups with other colleagues on specialized sport language tasks. This is a positive result, showing students' willingness to be active participants in the education and learning process. According to a research on personality types with students from the National Sports Academy, Zhelyazkova \& Mileva (2003) have established that sport students are mainly sociable, practical and realistic types of persons. They have good communicative skills and enjoy working with other people. The authors' conclusion is that using interactive learning techniques in the undergraduate and postgraduate education courses of the Academy would be appropriate for the personality characteristics and learning styles of sport students.

Pearson's chi-squared test $\left(\mathrm{x}^{2}\right)$, at $\mathrm{p} \leq .05$, was applied on the criteria of sex and faculty. The processed data have statistical significance on the criterion of sex in three of the questions. To the question what has helped them most to gain their present knowledge and skills in English, whether that was school education, language courses, computer games and internet activities or other sources, the results show that men have acquired most language knowledge and skills through computer games and activities in the internet $\left(x^{2}=7.093, p=.008\right)$. Consequently, using English for information and communication on the internet has given men not only language knowledge, but the confidence to use the language for their daily needs and interests. Women have relied on various other sources for language learning. To the question about the sources of sport information they most often use in English - newspapers, books, television, internet or other sources, the results show that men do not use television channels in English for sport information $\left(\mathrm{x}^{2}=4.558, \rho=.033\right)$. To the question about the evaluation of their own communicative language skills, there is also a difference between men and women $\left(\times^{2}=7.572, \mathrm{p}=\right.$ .056). The greater part of men evaluated their oral communicative skills as good by a four level scale (not good; good; very good; excellent). For the other questions in the survey, there are no differences with reference to the sex or the faculty of the students participating in it.

\section{Conclusion}

The results from the study can be summed up as follows. Students recognize using foreign languages as an important part of their professional qualification in the field of sport with reference to their future career development. They are interested in the practical application of foreign language learning. They have a positive attitude to using interactive techniques in the specialized language course. They need to develop their productive language skills - oral communicative and writing skills, in order to have the opportunity to use the language directly and to establish professional contacts with sport specialists from 
other countries. Finally, computer games and activities on the internet can act as a close to natural environment enhancing language acquisition.

\section{References:}

Brown, H.D.(1994) Teaching by Principles An Interactive Approach to Language Pedagogy, Prentice-Hall, Inc., USA

Gjurova,V. Bozhilova,V.,Valkanova,V. \& Dermendzhieva, G. (2007) Interactivnostta v uchebnya process (ili za ribaria, ribkite i ribolova). [Interactivity in the Learning Process (or about fish, the fisherman and fishing)], Europress, Sofia, 68-99. Ivanov, I.(2004) Teoriy za obrazovanieto.[Theories about Education], "Bishop K. Preslavski" University, Shumen.

Ivanova, V.\& Mileva, E. (2019) Teachers' Satisfaction with their Professional Activities in Physical Education and Sport, www.iseic.cz, www.journals.cz., 453-458.

Krasteva, A. (2003) Aspecty na ekypnoto obuchenye [Aspects of Team Learning] Faber, V. Tarnovo.

Mileva, E. (2019) Mladezki deinosti i sport - teoria i practica [Youth Activities and Sport - Theory and Practice], Avangard Prima, Sofia, 20-24.

Mileva, E.(2012) Evropeisky izmerenia na sportnopedagogycheskoto obrazovanie. [European Dimensions of Sport Pedagogical Education], Avangard Prima, Sofia, 164-5.

Prabhu, N. S.(1987) Second Language Pedagogy, OUP.

White Paper on Sport (2007) Commission of the European Communities, Brussels,1. Retrieved February 15, 2020, from https://eur-lex.europa.eu/legal-content/EN/TXT/?uri=celex:52007DC0391

Willis, J.(1996) A Framework for Task-Based Learning, Longman.

Zhelyazkova-Koynova, Zh.. \& E.Mileva. (2003) Vzaimovrazka mezhdu lychnostny typove i stylove na uchene pri student sportisty[Interrelations between Personality Types and Learning Styles with Sport Students] Sport, Society, Education (Vol.8), Sofia, NSA Press, 109-119. 